\title{
LIMNOLOGICAL AND BIOLOGICAL CHARACTERISTICS OF THE ALPINE LAKES OF PORTUGAL
}

\author{
M. J. Boavida \& Z. M. Gliwicz \\ Departamento de Zoología, Faculdade de Ciências, Universidade de Lisboa, Campo Grande C2, 1700 Lisboa, Portugal. \\ Department of Hydrobiology, University of Warsaw, Banacha 2, 02-097 Warsaw, Poland.
}

Key words: alpine lakes, zoopankton, planktivorous fish.

Palabras clave: lagos de alta montaña, zooplacton, peces planctivoros.

\begin{abstract}
This is the first limnological description of the so far unknown alpine lakes of Portugal. All located above $1500 \mathrm{~m}$ above sea level on granitic soil, these are small lakes of glacial origin and acidic nature. The biological structure is simple. The phyto- and zooplankton communities of the lakes without fish were compared with those of the lakes where trout (Oncorhynchus mykiss Walbaum) has been introduced. This study was undertaken for a short period of time ( September and October of 1993) and therefore it should only constitute a starting point for studies leading to preservation of these ecosystems of unique nature in the country.
\end{abstract}

\section{INTRODUCTION}

The scientific interest of this set of lakes stems from the fact that these are the only lakes of glacial origin in Portugal and also the only lakes located above timberline in the country. Serra da Estrela is a $2000 \mathrm{~m}$ altitude mountain in the central part of Portugal, following the Sierras which in central Spain separate Castilla-la-Nueva from Castilla-la-Vieja (RIBEIRO 1941). Snow and ice cover remains usually from January to May in the higher peaks. Precipitation usually starts in October (rain) and ends in May (below circa $800 \mathrm{~m}$, rain, above that and starting in January, snow). Annual precipitation in Serra da Estrela is 2000-2800 mm (ATLAS DO AMBIENTE, 1975). The high precipitation of Serra da Estrela in the relatively arid Iberian Peninsula is attributed to the fact that this is a large, massive mountain reaching high altitude at only about $100 \mathrm{Km}$ from the sea; the high altitude, the closeness to the sea, and the predominance of winds from west (i.e. from the sea) have as a consequence the observed high precipitation (RIBEIRO, 1941). Annual insolation corresponds to 2200-2500 hours (ATLAS DO AMBIENTE, 1975). Annual mean of daily temperature is below $10^{\circ} \mathrm{C}$ (ATLAS DO AMBIENTE, 1975). Above $1500 \mathrm{~m}$ vegetation is characterized by a mosaic-like covering of shrublands where Juniperus communis L. subsp. alpina is dominant, at times in co-dominance with Erica arborea $\mathrm{L}$. and also of mat grass lawns, open grass fields, and both rupiculous and lake communities (JANSEN, 1992). Both the flora and the climate correspond to the Mediterranean mountain type. Being all small, the lakes of Serra da Estrela are therefore subjected to a strong influence of the rigorous climatic conditions.

With the exception of a study on zooplankton and fish relationships (GLIWICZ \& BOAVIDA, 1996) and fish population studies (VALENTE et al 1994) there are no limnological data on the alpine lakes of Portugal. The first limnological description of ten of these lakes is made in this paper based on field measurements and samples collected on four occasions in September and October of 1993. The aim of this preliminary examination is to establish a starting point for long-term studies of'trophic status and biodiversity, leading to the preservation and conservation of the lakes in the near future. This kind of study is actually very pertinent to the interests of the official authorities, suiting their objectives of protecting the natural patrimony of Serra da Estrela.

\section{DESCRIPTION OF SITES STUDIED}

Among the ten lakes sampled in Scrra da Estrela five are natural lakes (Redonda, Escura, D. Angclo, Paixão, Salgadeiras), two are artificial (C. Ferro, Viriato), and three arc impounded natural lakes (Comprida, Serrano, C. Quelhas). The natural lakes are round shaped and mostly shallow, the artificial lakes (with the only exception of C. Ferro) and those natural which have been dammed have an elongated shape.

All located above an altitude of $1500 \mathrm{~m}$ (more precisely between $1550 \mathrm{~m}$ and $1840 \mathrm{~m}$ a.s.l. - Table 1) on granitic soil, 
the lakes can be separated into two groups: (I) those of River Mondego watershed - Redonda, Comprida, Escura, D. Angelo, Serrano, C. Quelhas; and (2) those of River Zêzere watershed Paixão, Salgadeiras, C. Ferro, Viriato. The drainage pattern is very interesting, being natural and artificial lakes alike related through intermittent and permanent streams eventually flowing into the two main rivers already mentioned. Both R. Mondego and R. Zêzere originate in Serra da Estrela. R. Mondego flows into the Atlantic, R. Zêzere is a tributary of R. Tejo, a large Iberian river flowing into the Atlantic also. A general description of the lakes is shown on Table 1.

The natural lakes of Serra da Estrcla were originally fishless and remained so until recently. It was only after 1983 that fish - Oncorhynchus mykiss Walbaum (former Salmo gairdneri Richardson) - was first introduced in a regular fashion. The small reservoirs have been only sporadically stocked with fish since their impoundment until 1983. According to the information gently supplied by the state institutions superintending fish stockings in the region, Oncorhynchus mykiss released into the lakes belong to the size range $5-8 \mathrm{~cm}$, which corresponds to fish 4-6 months old; stockings were done particularly in the reservoirs Comprida, Viriato, and C. Ferro in the last three years before this study was undertaken. One of the natural lakes. Escura, was stocked in 1992 and a couple of times before that (unknown dates). Therefore the ichthyofauna of these lakes consists uniquely of Oncorhynchus mykiss, with the exception of Comprida where Leluciscus spp. were accidentally introduced by fishermen.

Because all of these lakes are located inside the perimeter of a natural park - " Parque Natural da Serra da Estrela", with an area as large as 100,000 ha - fishing is allowed only with restrictions. Such restrictions are defined every year, following a governmental law of 30 July 1982, and they determine in which days of the week fishing is allowed, how many fish each fisherman is allowed to catch, the dimensions beyond which fish caught will have to he released back to the water, and the exact days of beginning and ending the annual fishing season (e.g. when this study was undertaken the fishing season started on 10 June and ended on 27 September, fishing was allowed for three days a week, and every fish smaller than $22 \mathrm{~cm}$ would have to be released). Moreover. fishing is allowed only from the shore, with no bait.

Mostly the lakes are devoid of littoral zone, being the rocky shores naked of macrophyte vegetation. Exceptions among those studied are Redonda, Paixão, and Escura.

\section{MATERIALS AND METHODS}

Water for total phosphorus and chlorophyll determinations was collected from 0.3-0.4 m depth directly into acid rinsed polyethylene bottles. Total phosphorus was determined after strong acid digestion at high temperature and pressure of whole water samples, followed by the molybdate blue test. Water for chlorophyll determination was filtered (Whatman $\mathrm{GF} / \mathrm{C}$ ) a few hours after collection, filters were dried and stored for later extraction in acetone.

Samples for phytoplankton study were also taken from the upper stratum as referred previously. The unfiltered samples were preserved immediately upon collection with Lugol's iodine solution. Identification and enumeration were done under a Nikon inverted microscope with a magnification of $200 \mathrm{X}$.

Zooplankton samples were taken with a conical tow net of $100, \mathrm{pm}$ mesh size and $9.5 \mathrm{~cm}$ mouth diameter. In deep lakes and when possible vertical tows were taken from a boat over the deepest part of the lake. In shallow lakes horizontal tows

\begin{tabular}{|c|c|c|c|c|c|c|c|c|c|c|}
\hline & REDONDA & COMPRIDA & ESCURA & D.ANGELO & SERRANO & C.QUELHAS & PAIXAO & SALGADEIRAS & C FERRO & VIRIATO \\
\hline hitude, m & 1620 & 1600 & 1680 & 1740 & 1790 & 1810 & 1670 & 1840 & 1580 & 1550 \\
\hline ea ha & 3 & 51 & 2 & 1 & 7 & 5 & 2 & 1 & 6 & 21 \\
\hline ax depth, ${ }^{*} \mathrm{~m}$ & 6 & 16 & 9 & 3 & 3 & 4 & 25 & 3 & 15 & 9.5 \\
\hline ochi, m & $\begin{array}{l}52 \\
23\end{array}$ & $\begin{array}{l}55 \\
81\end{array}$ & $\begin{array}{l}60 \\
82\end{array}$ & $\begin{array}{c}55 \\
>30\end{array}$ & $\begin{array}{c}41 \\
>3.0\end{array}$ & $\begin{array}{l}58 \\
32\end{array}$ & $\begin{array}{c}58 \\
>2.5\end{array}$ & $\begin{array}{c}59 \\
>3.0\end{array}$ & $\begin{array}{l}58 \\
80\end{array}$ & $\begin{array}{l}5.0 \\
1.5\end{array}$ \\
\hline $\begin{array}{l}\text { ratification } \\
\text { per meta- } \\
\text { mion }+, \mathbf{m}\end{array}$ & no & $\begin{array}{c}\text { yes } \\
6\end{array}$ & no & no & no & no & no & no & $\begin{array}{c}\text { yes } \\
2\end{array}$ & $\begin{array}{c}\text { yes } \\
4\end{array}$ \\
\hline
\end{tabular}

Maxinum depth for impoundments referes to sampling date

- When applicable. 
Tabla 2. Fósforo total y clorofila (ambos en $\mu \mathrm{g} / \mathrm{l}$ ) de diez lagos de la Sierra de la Estrella y sus comunidades fito-planctónicas (densidad algal en células o colonias por ml). Table 2 Chlcrophyll a and total phosphorus (both in $\mu \mathrm{g} /$ ) of ten lakes of Serra da Estrela and their phyroplankton communities (algal densities as celis of colonies per ml).

\begin{tabular}{|c|c|c|c|c|c|c|c|c|c|c|}
\hline$=$ & REDONDA & COMPRIDA & ESCURA & D ANGELO & SERRANO & C QUELHAS & PAIXAO & SALGADEIRAS & C FERRO & VIRIATO \\
\hline chlorophyll a & 17 & 04 & 1.5 & 07 & 22 & 22 & 17 & 09 & 15 & 2.0 \\
\hline total phosphorus & 39 & 07 & 27 & 14 & 17 & 12 & 22 & 09 & 12 & 2.2 \\
\hline Cryptomonas & 140 & 23 & 140 & - & 373 & 116 & 303 & 349 & 489 & - \\
\hline Mallomonas & - & - & 1793 & 1164 & 93 & 163 & 23 & - & 93 & 93 \\
\hline Dinobryon & 47 & 582 & 582 & 124 & 1164 & 1164 & 582 & 582 & 47 & 47 \\
\hline Peridinium & 186 & 233 & 163 & 47 & - & - & - & - & & - \\
\hline Micrasterias & - & - & - & - & - & - & - & - & & 2900 \\
\hline Spinocosmarium & 47 & - & - & - & - & - & - & - & & - \\
\hline Merismopedia & - & - & 23 & - & - & - & - & - & & \\
\hline Chroococcus & - & - & 93 & 23 & - & - & - & - & & \\
\hline Botryochoccus & 1956 & 279 & 140 & 163 & 1863 & 675 & 163 & 23 & & \\
\hline desmid* & - & - & - & 93 & - & - & - & - & & - \\
\hline flagellates* & 5263 & 908 & 466 & - & 2329 & 2631 & 280 & 186 & 746 & - \\
\hline nanoalgae* & - & - & - & - & - & - & - & - & & 548000 \\
\hline Bacillariophyceae & 186 & 47 & - & 628 & 93 & 116 & 70 & - & & - \\
\hline $\begin{array}{l}\text { Shannon index } \\
\text { (H') }\end{array}$ & 0.94 & 1.36 & 1.46 & 1.30 & 1.38 & 1.24 & 1.49 & 1.08 & 0.99 & 0.17 \\
\hline
\end{tabular}

unidentified

were taken from a boat keeping the net between I and 2 meters depth, or by throwing the weighted net from shore and pulling it close to the surface in those lakes where the more difficult access would prevent us from carrying the boat. Immediately upon collection samples were fixed in $4 \%$ formalin, sugar saturated aqueous solution. Later in the laboratory identification was performed under a Leitz Riomed microscope. at $40 \mathrm{X}$ and $100 \mathrm{X}$, and a Sedgewick-Rafter chamber was used for quantification.

Temperature and dissolved oxygen concentration of lakc water were measured with a YSI model 57 meter, $\mathrm{pH}$ was approximately determined with Johnsons indicator $\mathrm{pH}$ paper range 3.9 to 6.7 , and water transparency was evaluated with a $20 \mathrm{~cm}$ black and white Secchi disk.

Areas of the lakes were determined by planimetry on a 1:25000 topographical map.

\section{RESULTS}

Water $\mathrm{pH}$ was acid in all lakes, varying between 4.1 and 6.0 (Table 1). However, since this parameter could only be estimated with indicator paper, the values determined could be a little underestimated, being the actual, values slightly less acid than field measurements indicate. Surface dissolved oxygen concentrations were always high, close to saturation, in all lakes.

Littoral zone and macrophyte vegetation: In the three lakes where macrophyte communities can be found (Rcdonda.
Paixão, and Escura) these were constituted of very similar. although non coincident, plant associations. More important variation, though, was observed in the dimensions of the littoral zone which was evaluated by the extention covered by macrophytes: In Rcdonda the littoral zone corresponded to about one third of the total area of the lakc and completely encircled the open water; in Paixão the littoral zone corresponded to a narrow (2-3 meters) ring surrounding the whole lake; in Escura only about two thirds of the lakc perimeter were covered by macrophytes (to about 1.5-2 meters from shore) being the remaining shore constituted of bare rock. The description of the phytosociological characteristics of these three lakes follows, always from open water to shore.

Redonda: Potamogeton polygonifolius Pourret, AntinoriaRanunculus association (constituted by Antinoria agrostidea (DC.) Parl., occurring the aquatic variant subsp.natans (Hackel) Rivas Martinez only in Serra da Estrela and central Spain, and by Ranunculus ololeucos Lloyd), Junco Sphagnetum association (constituted by Juncus bulbosus L. and Sphagnum sp.) and Juncus effusus $\mathrm{L}$.

Paixão: Antinoria-Ranunculus, Junco-Sphagnetum, Carex nigra (L. ) Reichard and Juncus effusus L. In this lakc the water fluctuation was appreciable; on the wet halt-meter ring surrounding the whole lake we found Sphagnum sp. with Viola palustris L. and Carex nigra (L.) Reichard sometimes interrupted by spots of Polytrichum sp.

Escura: Antinoria-Ranunculus, Junco-Sphagnetum, and Juncus bulbosus $\boldsymbol{L}$. 
Tabla 3. Densidades de zooplancton (ind./l) y índice de diversidad de Shannnon ( $\mathrm{H}^{\prime}$ ) para los diez lagos alpinos estudiados en la Sierra de la Estrella. Los números entre paréntesis representan, en \% la comunidad zooplanctónica.

Table 3. Zooplankton densities (ind./l) and Shannon's diversity index $\left(\mathrm{H}^{\prime}\right)$ for the ten alpine lakes studied in Serra da Estrela. Numbers in parentheses represent $\%$ contribution to the zooplankton community.

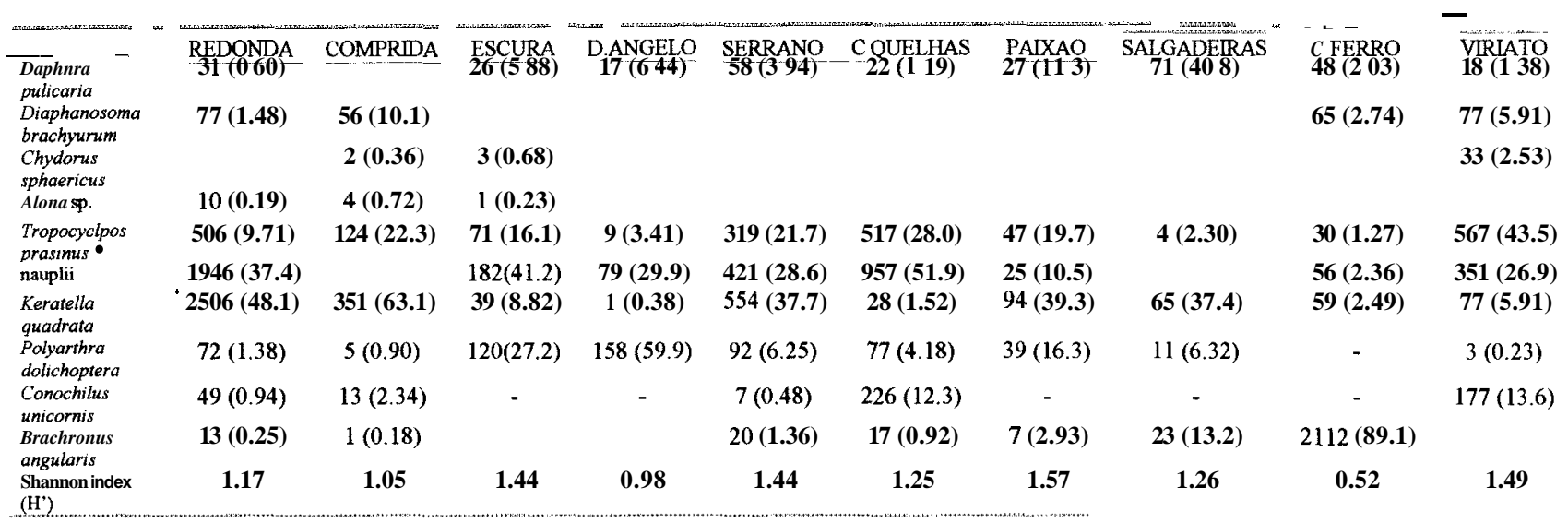

$\approx$ copepodites included

Phytoplankton and related parameters: The phytoplankton communities of Serra da Estrela lakes are very simple (Table 2) and comprised mainly of unicellular algae of suitable dimensions to be consumed by herbivore zooplankters. Cryptomonas, Mallomonas, as well as other flagellates, were abundant in most lakes. There were practically no Cyanophyceae. The only colonial alga present in all lakes was Dinobryon which was most abundant in Serrano and C. Quelhas, two fishless impounded natural lakes connected through a very small channel. Next to these lakes in Dinobryon abundance were Salgadeiras, Comprida, Paixlio, and Escura. Of these, three are natural lakes, one with fish (Escura), two with no fish (Salgadeiras and Paixão) Only one large colonial alga was found to be a relevant presence in the set of studied lakes: Botryococcus (B. braunii). The only lakes where Botryococcus was not found were C. Ferro and Viriato, two small reservoirs frequently stocked with fish and in which trout keeps a fairly high density.

Shannon diversity index concerning the phytoplankton community of each lake ( $\mathrm{H}^{\prime}$, Table 2) was low for all lakes and it was comprised between 0.17 and 1.49 . There were no differences respecting $\mathrm{H}^{\prime}$ for phytoplankton between natural and impounded lakes ( $F_{0: 15(2)} 4,4=4.44,0.20>P>0.10$ )

Regarding the analysis of lakes with fish vs. lakes with no fish, however. a significant difference was found between diversity indexes of the two groups of lakes $\left(F_{0.115(2) .3 .5}=8.52\right.$, $0.05>\mathrm{P}>0.02$ ).
Similarly to what happens with other mountain lakes, both chlorophyll $n$ and total phosphorus (Table 2) were low in Serra da Estrela lakes.

Zooplankton communities: The number of species constituting the zooplankton community of each of the lakes varied between 4 and 8 . In the whole set of lakes four Cladocera, one Copepoda, and four Rotifera were identified (Table 3). In lakes D. Angelo, Serrano, C. Quelhas, Paixão. and Salgadeiras, there was only one cladoceran, in C. Ferro two cladocerans, and in lakes Redonda, Comprida, Escura, and Viriato, three cladocerans. In the lakes with only one cladoceran species this was Daphnia pulicaria, which was present in all lakes but Comprida. Daphnia pulicaria was the only cladoceran found in all fishless lakes but Redonda, where Diaphanosoma brachyurum and Alona sp. together made up a fraction of $73.6 \%$ of the cladocerans.

The most abundant zooplankter was a rotifer in almost all lakes. Keratella quadrata was the most abundant in lakes Redonda (48.1\%, Comprida (53.1\%), Serrano (37.7\%) and Paixão $(39.3 \%)$. Polyarthra dolichoptera was the most abundant in lakes Escura (27.2 \%) and D. Angelo (59.9\%). Brachionus angularis was the most abundant in C. Ferro (89.1 $\%)$. Only in three of the studied lakes the most important zooplankter was not a rotifer. The copepod Tropocyclops prasinus (both adults and copepodites) was the most abundant in lakes C. Quelhas (28.0\%) and Viriato (43.5\%). Daphnia pulicaria was the most abundant zooplankter in Salgadeiras (40.8\%). 
Shannon diversity index concerning zooplankton community of cach lake ( $\mathrm{H}^{\prime}$, Table 3 ) was relatively low for all lakes and it was comprised between 0.52 and 1.57. Likewise with respect to phytoplankton, no significant differences concerning $\mathrm{H}^{\prime}$ for zooplankton communities were found when comparing natural with impounded lakes $\left(F_{0.0512) 4.4=2.91,0.05}>\mathrm{P}>0.20\right)$. On the other hand, and unlike what happened for phytoplankton with respect to presence and absence of fish, no significant difference was found in $\mathrm{H}^{\prime}$ for zooplankton between the two groups of lakes (Fo.015(2) 3.5 $=4.73$, $0.20>\mathrm{P}>0.10$ ).

Ichthyofauna: Fish are found only in a few lakes, since, as stated before, all lakes were originally fishless. Lakes with fish are Comprida. Escura, C. Ferro. and Viriato. In all of these fish officially introduced was rainbow trout Oncorhynchus mykiss Walbaum. In Comprida there are also Leuciscus spp. which have been introduced by fishermen and have been reproducing to large quantities.

Stockings apparently wcre not done with the purpose of keeping a more or less constant density - there are no trends in the last three years in which stockings have been consecutive (Table 4). There are no data on fishing efficiency taking place every season on each lake.

With no means to estimate actual fish density in the four lakes - no echo sounder, not even empirical data to calculate differences between number of stocked fish and number of fish caught by fishermen - only direct observation underlies the judgments that fish density is much higher in Comprida, followed by lakes C. Ferro and Viriato, where fish density is intermediate, being finally Escura the only one with lower fish density. If these observations wcre considered as being quantitatively expressed by abstract numbers, so that a gradient could be established, one would say that Comprida corresponds to level 3 in fish density, C. Ferro and Viriato correspond to level 2, and Escura corresponds to level 1

Relating what was just stated to presence and abundance of the larpcr cladoceran: I. among the lakcs with no fish Daphnia pulicaria is the only cladoccran (100\% of the cladoccrans) in the zooplankton community in all lakes but Redonda; II. where fish density corrcsponds to level 1 Daphnia pulicaria constitutes more than $80 \%$ of the cladocerans; III. where fish density corrcsponds to level 2 Daphnia pulicaria constitutes a fraction lower than $50 \%$ of the cladocerans; IV. where fish density corresponds to level 3 Daphnia pulicaria was not found at all ( $0 \%$ of the cladocerans).

Trophic State of the lakes: Computed values for the three components of Carlson's Trophic State Index (CARLSON, 1977) are elucidative of the quality of the water of the studied lakes. Because significant changes in total phosphorus, chlorophyll, and Secchi disk transparency were not expected to occur during the study period in these almost left alone lakes, the index was calculated with basis on one single measurement of cach of the three parameters for each lake. Only in the cases where the calculations would not make sense (i.e. the transparency component when Secchi disk was visible to the bottom) the transparency component of the index is not indicated. The only high value of the Trophic State lndex is that obtained for the transparency component in Viriato (Table 5). The values of the index for both the chlorophyll component and the phosphorus component for the same lake, however, arc low. This is an indication that turbidity of the water in Viriato was probably caused by inorganic seston brought from the surrounding land rather than by live phytoplankton.

With the only exception of the above cited transparency index for Viriato, all of the calculated indexes for all lakes are included within the oligotrophic range for Vollenwcider's lakes. In fact, the three components of the index were computed for minimum and maximum values of a table modified from VOLLENWEIDER (1979) and published in WETZEL (1983). Carlson's index calculated with minimum and maximum values of the referred table for total phosphorus, chlorophyll, and Secchi disk for oligotrophic lakes determined a range for each of the corresponding components of the index for lakes classified by Vollenweider as oligotrophic. Based on this all lakcs studied in Serra da Estrela can be classified as oligotrophic.

Tabla 4. Poblaciones de peces ( $n{ }^{\circ}$ por ha) en los lagos en que ha sido introducida la trucha.

Table 4. Fish stockings (n." fish per ha) in those lakes were rainbow trout has been introduced

$\begin{array}{ccccc} & \text { COMPRIDA } & \text { ESCURA } & \text { C. FERRO } & \text { VIRIATO } \\ 1983 & 471 & & - & 643 \\ 1987 & 20 & & - & 48 \\ 1991 & 1275 & - & 6667 & 2381 \\ 1992 & 1291 & 500 & 959 & 1768 \\ 1993 & - & & 8417 & 1902\end{array}$




\section{DISCUSSION}

Both phytoplanktonic and zooplanktonic communities are very simple in all of the studied lakes. as should be expected. In a survey of the algal flora of 87 lakes located in the High Tatra Mountains (Slovakia) LUKAVSKY (1994) reported, for summer phytoplankton and among others, the following genera which wcre also found in Serra da Estrcla: Merismopedia, Chroococcus, Cryptomonas, Dinobryon, Peridinium, Mallomonas, and Botryococcus. The lakes referred to in the above cited study, such as those reported here, are of glacial origin, most of them are oligotrophic, and the area where they are located is constituted of granitic rock. Among the algae common to both Tatra Mountains and Serra da Estrela lakes, Cryptomonas is considered to be very good food for Daphnia pulicaria, favoring high levels of survival and reproduction $(C$. reflexa was the species used in experiments; STUTZMAN, 1995). The zooplanktonic communities of other oligotrophic lakes in the Tatra Mountains are even simpler (GLIWICZ, 1985) than those of the lakes reported in the present study. In the lakes studied by CLIWICZ (1985) there were only one copepod and two rotifers - no cladocerans at all. In Serra da Estrela lakes even the simplest zooplanktonic community (that of D. Angelo) was composed of 4 species. It is interesting, however, that in lake D. Angelo there is one copepod and two rotil'ers (being the rotifers the same genera as in Tatra lakes). In addition to these 3 species there is also one cladoceran in D. Angelo: Daphnia pulicaria. This difference could be attributed to the fact that there is no fish in the Estrela lake, unlike what happens in the referred Tatra Mountains lakes, all stocked with salmonid fish. By virtue of its large dimensions. Daphnia pulicaria becomes very much vulnerable to fish predation

On the other hand, the percentage of the largest cladoceran in the lakes Redonda and C. Quelhas, both with no fish, was low ( 0.60 and 1.19 of the zooplankton. respectively). This could be an indication that planktivorous fish was not the only predator on Daphnia pulicaria. In both lakes Tropocyclops prasinus was very abundant. Therefore. and similarly to what has been observed with respect to other cyclopoid copcpods (GLIWICZ \& UMANA, 1994; GLIWICZ \& LAMPERT, 1994) the copepod Tropocyclops prasinus may be an important predator on Daphnia pulicaria in these fishless lakes.

It may be argued that different ways of sampling zooplankton, impossible to avoid in this study, might also have influenced these results. However, in the most contrasting lakes with respect to the relationships zooplankton/fish and D. pulicaria/T. prasinus, namely lakes Escura, Viriato, Serrano. C. Ferro, Redonda, and C. Quelhas, zooplankton was sampled in the same way: by means of horizontal tows.

Values found for parameters such as chlorophyll a and total phosphorus in Serra da Estrela lakes are of the same order of magnitude as those found for similar mountain lakes, e.g. FAAFENC \& HESSEN (1993). The same is true for parameters such as $\mathrm{pH}$; even considering that the estimated $\mathrm{pH}$ could be somehow lower than the actual $\mathrm{pH}$ of the lakes, values determined for Serra da Estrela lakes match those found in the literature for the same type of ecosystems (KOPACEK et al., 1995). In fact, subsequent comparison between the values estimated with the indicator paper used in the field and those read out of a $\mathrm{pH}$ meter in the laboratory evidenced very small differences: 0.1-0.3 of a $\mathrm{pH}$ unit; since differences between $\mathrm{pH}$ values determined with a $\mathrm{pH}$ meter and those estimated by $\mathrm{pH}$ paper (both done later in the laboratory) wcre very low, it was assumed that $\mathrm{pH}$ estimated in the field for Serra da Estrela lakes was not too far from the exact values.

As to the ichthyofauna of Serra da Estrela lakes, it would have been interesting, in order to see the effects of stocking, to compare the biological (phytoplanktonic and zooplanktonic. especially) communities of the time before trout with the communities of the same lakes after fish introduction. Since that could not be done due to lack of previous studies, the only alternative was to compare the communities of the lakes with fish with those of the lakes with no trout.

Our findings corroborate the scientific literature on the subject. The non existence of Daphnia puticaria in Comprida. which is the lake with highest fish density among those studied

Tabla 5. Índice de estado trófico de Carlson para los diez lagos alpinos estudiados en la Sierra de la Estrella. TP - componente lósforo del índice Ch. componente clorofila del indice SD - componente transparencia del índice.

Table 5. Carlson's Trophic State index for the ten alpine lakes studied in Serra de Estrella. TP - phosphorus component of the index. Ch1. - chlorophyll component of the index. SD - transparency component of the index.

\begin{tabular}{|c|c|c|c|c|c|c|c|c|c|c|}
\hline & REDONDA & COMPRDA & ESCURA & D.ANGELO & SERRANO & C.QUELHAS & PAIXAO & SALGADEIRAS & C.FERRO & VIRIATO \\
\hline $\mathrm{TP}$ & 24 & 0 & 18 & 9 & 12 & 7 & 16 & 3 & 7 & 16 \\
\hline Chl. & 36 & 22 & 35 & 27 & 38 & 38 & 36 & 30 & 35 & 37 \\
\hline $\mathrm{SD}$ & 43 & 30 & 30 & $\mathbf{n S}$ & ns & 43 & ns & ns & 30 & 54 \\
\hline
\end{tabular}

ns - no sense in derermining the index (Secchi disk visible down to the botom of the lake) 
(see "ichthyofauna" in the "results" section), could be interpreted as extinction of this large cladoceran in the lake. Onc argument in favor of the cxtinction is that Daphnia pulicaria is the only large cladoceran present in all other lakes in the area. independently of whether there is or there is not fish in them. It would not be shocking to assume that this large bodied daphnid was also part of the fauna of Comprida before the existencc of trout. Another argument in favor of extinction is that Comprida receives water flowing in from Escura, where Daphia pulicaria is fairly abundant. The extinction of the large Cladoccran is a phenomenon similar to what has been observed in other lakes as a consequence of stocking with planktivorous fish (GLIWICZ, 1980).

In addition to the (direct) effect produced on zooplankton by fish, which is materialized not only through the observed differences in Daphnia pulicaria densities pointed out in this paper but also through differences in body length and clutch size of the same animal reported for Serra da Estrela lakes (GLIWICZ \& BOAVIDA, 1996), there might be another (indirect) effect produced lower in the trophic cascade by fish: The Shannon diversity for phytoplankton on lakes with fish was significantly distinct from that of lakes with no fish. Still at the phytoplankton level, Botryococcus is by far much mose abundant in lakes such as Redonda. Serrano, and C. Quclhas (Table 2) which have no fish. When fish predation pressure on zooplankton is high, the pressure exerted by zooplankton on phytoplankton is proportionately lower. It does make sense that, in the lakes with no fish and therefore where the grazing pressure on the phytoplankton community would be expected to be higher, the colonial alga Botrvococcus braunii, which mucilaginous envelope rends it inedible for zooplankton, was found in appreciable amounts (as a phytoplankton defense against grazing.

In conclusion, general limnological characteristics of the mountain lakcs of Portugal are similar to those of other mountain lakcs in other parts of the world. The quality of their waters can bc considered as good. The objectives of protection and conservation of these lakes within the frames of a natural park will apparently face the dilemma of either natural resource prcscrvation or social development (especially touristic) of the area. The solution is to allow social development always within the limits of planned management, so that these ecosystems unique to the country will not be pushed beyond the recovery point.

\section{ACKNOWLEDGMENTS}

Partial financial support was provided by Fundação Calouste Gulbcnkian (Portugal) in the form of a Gulbenkian Professorship to Z M.G. Parquc Natural da Serra da Estrela provided logistic support. Wc thank M.J. Caramujo for copcpod identification. Data on fish stockings were provided by Centro Aquícola do Rio Avc and by Administração Florestal de Manteigas. This paper is a contribution from Centro dc Biologia Ambiental, Universidade de Lisboa.

\section{REFERENCES}

ATLAS DO AMBIENTE. 1975. Maps of distribution of precipitation, insolation. and temperature (in Portuguese). Comissão Nacional do Ambicnte.

CARLSON, R.E., 1977. A trophic state index for lakes. Limnol. Oceanogr. 22: 361 -369.

FAAFENG, B.A. \& D.O. HESSEN, 1993. Nitrogen and phosphorus concentrations and $\mathrm{N}: \mathrm{P}$ ratios in Norwegian lakes: perspectives on nutrient limitation. Verh. Internat. Verein. Limnol. 25: 465-469.

GLIWICZ, Z.M., 1980. Extinction of planktonic cladoccran species from alpine lakes stocked with fish planktivores. In S. Horic (cd.), Paleolimnolgy of Lake Biwa and the Japanese Pleistocene. Kyoto University Press; 8: 3-22.

GLIWICZ, Z.M., 1985. Predation or food limitation: an ultimate reason for extinction of planktonic cladoceran species. Arch. f. Hydrobiologie 21:419-430.

GLIWICZ, Z.M. \& M.J. BOAVIDA, 1996. Clutch size and body size at first reproduction in Daphnia pulicaria at different levels of food and predation. J. Plankton Res. 18(ó): 863-880.

GLIWICZ, Z.M. \& W. LAMPERT, 1994. Clutch-size variability in Daphnia: body-size related effects of egg predation by cyclopoid copepods Limnol. Oceanogr: 39: 479-485.

GLIWICZ, Z.M. \& G. UMANA, 1994. Cladoceran body size and vulnerability to copepod predation. Limnol. Oceanogr. 39: 419-424.

JANSEN, J., 1992. A preliminary account of the study of shrubland vegetation in the upper parts of the Serra da Estrela, Portugal Interin report on behalf of the "Kuratorium der Reinhold-Tuxen-Gesellschaft". 13 pp.

KOPÁCEK, J., PROCHÁZKOVÁ, E. STUCHLIK \& P. HLAZKA, 1995. The nitrogen-phosphorus relationship in mountain lakes: influence of atmospheric input, watershed, and pH. Limnol. Oceanogr. 40: 930937.

LUKAVSKY, J., 1994. Algal flora of lakcs in the High Tatra Mountains (Slovakia). Hydrobiologia 274: 65-74.

RIBEIRO, O., 1941. Contribution to the study of sheep pasture in Serra da Estrela (in Portugucsc). Revista da Faculdade de Letras, vol VII 1-2 213-303.

STUTZMAN, P., 1995. Food quality of gelatinous colonial chlorophytes to the freshwater zooplankters Daphnia pulicaria and Diaptomus oregonensis. Freshwater Biol. 34: 149-153.

VALENTE. A., N. FORMIGO \& C. MAIA. 1994. The ichthyofauna of Parque Natural da Serra da Estrcla lakcs (in Portugucsc). Actas do 11 Seminário Técnico sobrc Conservação da Natureza na Serra da Estrela. 67-75.

VOLLENWEIDER,R.A., 1979. Das Nahrstoffbelastugskonzept als Grundlage für den externen Eindriff in den Eutrophierungsprozcss Stehender Gewässer und Talsperren. Z. Wasser-u. Abwasser-Forschung 12: 46-56.

WETZEL, R.C., 1983. Limnology, Second Edition. Saunders College Publishing, N.Y., 767 pp. 